William W. Derbyshire

CDU $808.1-47 /-49$

Rutgers University, New Brunswick

\title{
SOME COMMENTS ON THE ORIGIN OF HOMONYMY IN THE SLAVIC LANGUAGES*
}

In this paper we shall focus our attention on several aspects of the origin and nature of homonymy, drawing examples from Russian and Serbo-Croatian and other Slavic languages. We shall first view this from a diachronic perspective noting some of the reasons for the appearance of homonyms. Then we shall examine the phenomenon at the synchronic level employing a variant of Serbo-Croatian in which important phonetic changes now in process have given rise to new homophones. We may begin by turning to the ancestor of both Russian and Serbo-Croatian, Common Slavic. Homonymy appears to be a linguistically universal phenomenon, and it is safe to assume that there were homonyms in Common Slavic. One pair of such words was undoubtedly the infinitive pasti 'to graze' (pasp) and 'to fall' (padq) which has its reflexes in most of the modern Slavic languages, e.g. Serbo-Croatian pásti and pästi or Russian pastí and past' and Ukrainian pásty. Another pair was ključ found both in Russian (ključ) and Serbo-Croatian (kljûč) with the original meanings 'key' and 'spring (of water)'. In addition to inheriting already homonymous words from an earlier period, a number of doublets in the various Slavic languages have been created as the result of systematic sound changes. Here we might take as an example the Rus-

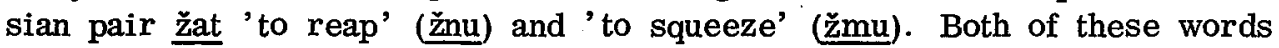
contained different nasals which fell together due to regular sound changes

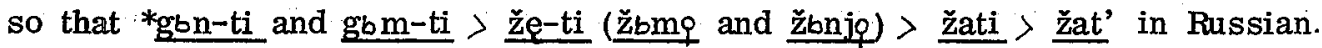
By means of a similar process in which the nasals emerged as $/ e /$, the same words in Serbo-Croatian took on the forms žěti (žänjem and żnjêm) and žeti (žmêm). Another important sound change which did not occur in Russian but which may be found in Serbo-Croatian as well as Czech is the neutralizing of the vowels $/ y /$ and $/ i /$. into a single vowel $/ i /$. Thus 'to beat' and 'to be' in Serbo-Croatian both emerge as biti in the infinitive form and a homophonous pair bíti and býti in Czech.

Homonyms inherited from Common Slavic or created through regular sound changes since that time constitute only a small percentage of the total in any given modern Slavic language. Far more numerous are incidences of phonetic coincidence created by homoforms, word formation and borrowing. Homoforms, or partial homonyms, are particularly common in the Slavic

This paper was read in a slightly altered form at the Kentucky Foreign Language Conference on April 23, 1976. 
languages due to the nighly developed system of inflections still a part of the morphologic structure of most Slavic languages. Such homoforms may belong to different, or somewhat less commonly, to the same grammatical categories. This can be seen in the following examples from Russian and Serbo-Croatian:

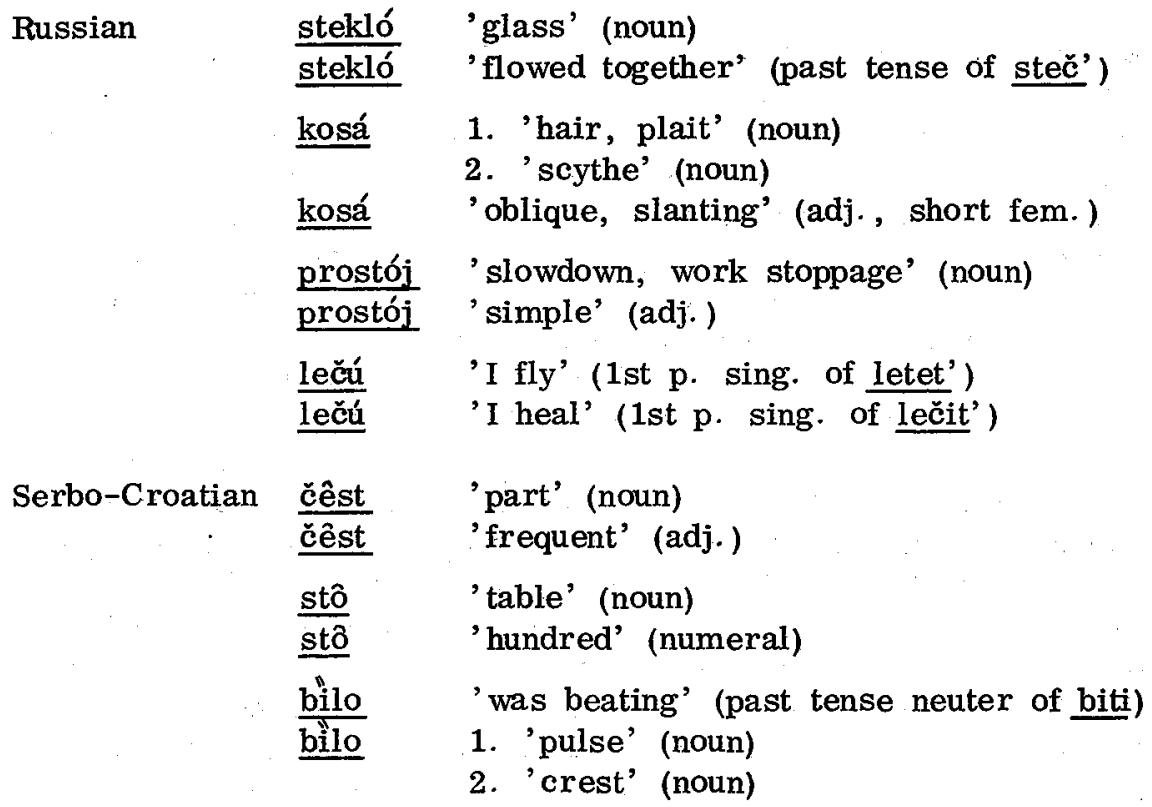

A very large number of homonyms are created in the process of word formation in both Russian and Serbo-Croatian. We see an example in bumažnik in Russian in which the word with its meaning 'worker in the paper industry' is derived from bumažn-ik and 'wallet' from bumaž-nik. Automatic internal phonetic changes in the word derivation process also create Russian homonyms as in the pair paivat', a secondary imperfective verb created from two different primary imperfectives, poit' 'to give drink to' and pajat' 'to weld'. Verbal prefixation also gives rise to a number of interesting pairs in which the homonymous element is contained in the prefix rather than the verb itself. If we take the pair prosmotret' we see that the prefix is the carrier of two ambiguous, indeed contradictory, meanings. When a professor says Ja prosmotrel vaš doklad, he might mean that he looked it through (over) or that he overlooked it! In some instances the prefixed verbs belong to different aspects as in sxodit' 'to descend', imperfective of sojti, and sxodit' 'to make a quick round trip on foot', a perfective verb which has no imperfective form. Similar derivational homony$\mathrm{ms}$ may be established for Serbo-Croatian as well. Let us consider, for example, razorávati, a secondary imperfective verb derived from both ra- 
zòrati 'to plow' and razòriti 'to destroy' or ûsšni, and adjective from ûs̆ 'louse' and ûho (üvo) 'ear'.

One of the most important sources of homonyms in any language is through the process of borrowing. Very often loanwords, which undergo phonetic adaptation in the borrowing process, emerge in the recelving language as homophonous with an already existing word. In Russian, for example, we find the native Slavic word brak 'marriage' forming a homonymous pair with a borrowing from German brak (Brack). A pair which exists for both Russian and Serbo-Croatian is bor (Serbo-Croatian bôr), the Slavic root for 'pine (forest)' together with the chemical term for 'boron' borrowed from Arabic via Middle Latin. Russian has numerous loanwords of this type from Dutch, English, German and French, while Serbo-Croatian boasts a rather lengthy list which includes many words of Turkish origin, particularly in Serbian and the eastern Croatian variants, while for Croatian in the coastal and inland western areas the list is supplemented by words from Italian and German. An example of a Slavic and Turkish root coinciding is b6j 'struggle' and its borrowed mate 'storey, floor', while from Italian we have bäla 'bale' together with the native 'mucus'.

It is not at all uncommon to find pairs or groups of words in which both or all partners are borrowings, normally from different languages. We see this in the English word punch which takes its three meanings from three different languages: 'beverage' from Hindi, 'hit' from French, and 'a puppet' from Italian. Here we can also take several examples of English words in Russian with the second partner from still another language, e.g. xeder 'a header, part of a combine for reaping' and 'a Jewish religious school for boys' from Hebrew hedher; rejd from 'raid' (military usage) and a Dutch word meaning 'place to anchor boats off shore, marina'; bar 'a drinking place, night locale' and 'a bar for a machine' and from the French word for barre 'sand bar', as well as 'a unit of atmospheric pressure' from Greek; finally liver with both of its meanings from English, 'liver' and 'lever'. Examples from Serbo-Croatian in which both members of a homonymic pair are loanwords include kôr 'corps' from French and 'chorus' from Greek xopos ; gêm 'tennis game' from English and 'pelican' from Hungarian gem; or bína 'stage' from German Bühne and 'building' from Arabic biná via Turkish.

In the preceding discussion we have examined just a few of the basic issues involving ambiguity and its relationship to phonetic coincidence in the form of various aspects of homonymy. By drawing our examples from Russian and Serbo-Croatian, we may gain a sense of the extent of the occurrence of homonyms in these languages, their origin and conflicts which arise from words with the same phonetic shape. Let us now turn our atten- 
tion to a description of the process of the formation of homonyms at the synchronic level taking place in one regional Croatian variant used by a significant number of speakers in Zagreb, the capital of Croatia, that republic's most influential city politically and culturally.

Implicit in the earlier part of this paper is the acceptance of the system of four accents and tones plus post-accentual length found in most formal descriptions of the standard literary Serbo-Croatian language. Yugoslav and foreign linguistis alike have long noted discrepancies in this system, but they have usually directed their attention to regional and village dialects. Significant divergences occuring in the country's two major cities, Belgrade and Zagreb, have been overlooked for the most part. Some literature on deviation in post-accentual length in large urban areas has been published by leading linguists such as Pavle Ivić, but the entire prosodic system as traditionally described and accepted seems to have remained unchallenged. In a recent book written by two non-Yugoslav linguists, Thomas Magner and Ladislav Matejka, the system as canonized by Vuk Karadžić and refined by his followers has been opened to discussion. 1 In their work Magner and Matejka present findings based both on perception as well as reproduction of speech by native speakers throughout Yugoslavia, which indicate that the traditional system is in need of a new description. Vowel lengths and tones are not only poorly articulated in certain areas, but they are not even heard by many speakers of Serbo-Croatian. If this is true then, what are the consequences as relevant to the topic of phonetic coincidence and ambiguity?

In classical descriptions of the language, accents and tones constitute phonemic distinctions in Serbo-Croatian. Thus, two words with short vowels and in all aspects identical with the exception of pitch may be distinguished merely by the presence of a rising or falling tone, as in zdrầvica 'toast' and zdràvica 'subsoil' or pầra 'steam' and pàra 'unit of money'. Likewise, words with a long vowel may be distinguished semantically by a rising or falling tone, e.g. râvan (n.) 'flat surface' and rávan 'level' (adj.) or Lûka 'Luke' and lúka 'harbor'. In fact, in Zagreb it appears the rising and falling tones have become neutralized, so that the words formerly distinguished only by their presence have now taken on the same phonetic shape. Thus we see the transformation of what were once homographs into homophones.

Further, although one certainly still hears vowel length pronounced in Zagreb, there is some considerable proof that for many speakers even long

1 Thomas F. Magner and Ladislav Matejka, Word Accent in Modern Serbo-Croatian, University Park (Penna.) \& London, 1971. 
and short vowels are on their way to being neutralized and that existing long vowels result from concomitant lengthening under stress. This would then imply the ultimate loss of short and long vowels as forming phonemically opposed linguistic units. Proof for this may also be found in Magner and Matejka's tests of such presumably distinctive pairs as gräd 'hail' and grâd 'city' or Péro 'Pero (a proper name)' and pèro 'pen' which young people born and raised in Zagreb have diffuculty distinguishing. This would mean that the following pairs formally distinguished by tone and quantity merge too: lûk 'bow' and lûk 'onion' or cuurak 'fur-lined coat' and cúrak 'tom turkey'. Similarly the sentences Sât ću vam pjêvati 'I shall now sing for you for an hour' and Săd ću vam pjëvati 'I shall now sing for you' could well be confusing and ambiguous. The following vowel length tongue twister is commonly used as a pun in Zagreb to test one's ability to reproduce tones and vowel lengths and at the same time understand the meaning:

Gòrē gôrē gơre gồre neg(o što) gòrē gòre dôlje.
verb adv. noun adv.
(gòrjeti) 'worse'
'The (mountain) forests above are burning worse
than the (mountain) forests are burning below.'

Predictably for certain natives of the Zagreb area all of the words gore have the same phonetic shape.

If vowel length under stress is modified, it is reasonable to expect that long vowels in non-accented position should also shorten. This is indeed the case in Zagreb. The absence or presence of post-accentual length in Serbo-Croatian is of some considerable importance to several categories in the morphologic system of that language, including the distinction of genitive singular and genitive plural for the majority of masculine and neuter nouns, long and short adjectives, the verbal tense system, to name just a few. It is interesting to note that in recent times there is a growing tendency for the standard language, much less its spoken non-literary variants, to lack formal distinctions between definite and indefinite adjectives. Very often that distinction lies exclusively in the presence or absence of a long vowel, e.g. löša - löšă 'bad' or vêselo - vêselō 'happy'. Some random tests which $I$ ran on Zagreb natives indicate that even those adjectives whose meanings are distinguished between definite or indefinite by the place of accent as opposed to tone or quantity are often not understood in that capacity. There is a distinct trend to normalize stress, so that in the four adjectives màlen(a), zèlen(a), cr̀̀ven(a), dàlek(a), all short forms whose feminine forms should change the place of stress to the second syllable, the preference of those responding was to maintain the place of stress on the first syllable, which happens to be the correct syllable for the long adjective. 
With regard to post-accentual length in verbal forms, we may point to the growing bookishness in the use of the aorist and imperfect tenses. There is little doubt that confusion between such forms as the imperfect čitāh 'I was reading' and citah, the aorist form 'I read' led to the downfall of these tenses. The same could be suggested for the third person singular forms of the aorist čità (or čita) '(he) read' and the present čitā. For example, it is difficult, even in context, to decide whether the verb in the following sentence is present tense or an aorist used to add coloring as a historical present:

Policájac pògleda/pògledā sve prìsutnē sùmnjičavīm pöglēdom. The policeman looked/looks at everyone present with a suspicious glance.'

The question of the genitive plural is a more difficult one and perhaps more relevant since it does not represent a dying category as is the case with long adjectives and the imperfect and aorist tenses. For the vast majority of masculine and neuter nouns in Serbo-Croatian the genitive singular and the genitive plural ending is $/ a /$, short in the singular and long in the plural. When Vuk was formulating his grammar in the last century, consideration was given to adopting into permanent usage an ending other than - $\underline{\bar{a}}$ for the genitive plural. His preference was for the regional $-\underline{a h}$, an ending widely used then and now (as is the ending -ov), in many variants. His major argument was precisely that ambiguity might be avoided between singular and plural forms. His suggestion did not find acceptance, and the standard emerged as an opposition between long and short $/ a /$. In the $a b-$ sence of any real distinction in Zagreb, there arise instances of ambiguity between sentences such as:

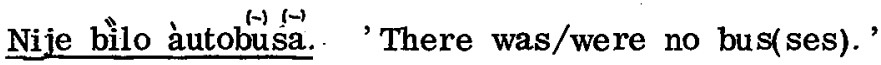
Vládo se bòjî rŭ̀să.'. 'Vlado is afraid of the Russian(s).'
Devètnaestí vìjek je vrijème vềlikih podùhvātā za proučávanje jềnik
'The nineteenth century is the time of great advances (projects) in the study of language(s).'

As noted earlier, the possible ambiguity which results in most cases of phonetic coincidence is not a particularly disruptive feature of the language. Nevertheless, not every case is unambiguous and its avoidance in Croatian is of some interest. The most obvious solution to disambiguate sentences such as the above is through the insertion, consciously or unconsciously, of a modifier which will act as a marker of the case being used. Thus the sentence Vládo se bòjī rû̉sầ becomes, for example, Vládo se bòjī òvog(a) rùsa or vládo se bòjī òvih rûsā. There are other possibilities. Magner and Matejka provide and interesting example of an accent shift which 
could indicate a trend in methods employed by speakers to disambiguate. The word pròfesor has as its genitive singular and genitive plural identical forms except that in the plural form both of the last two vowels are long. In some cities of Yugoslavia this word and others like it undergo an accent shift to another syllable. This phenomenon clearly serves to mark the difference between two otherwise ambiguous forms. In Split, a coastal city within the Croatian area, the expected prôfesōrā becomes for some speakers profesorra in the genitive plural. The same may be observed among speakers of Titograd and Subotica. Likewise the word ribār has as its genitive plural ribára rather than the anticipated ribārā. (Both ríbara and ribára have been noted in Zagreb).

Where the trends described here will lead is of course unknown. There are those who insist that the prescriptive grammarians will ultimately be successful in bringing all speakers of Serbo-Croatian to a unified pronunciation, with a modified Vukovian norm winning out. If that happens, many of my findings here will cease to be relevant and will no longer constitute real speech differences in the Serbo-Croatian community. On the other hand, some see a further disintegration of old norms and the widening of differences between Serbian and Croatian. My findings would then be subject to a further expansion.

In the preceding we have presented briefly several factors which lead to homonymy in Slavic languages. Each of these in turn have parallels which may be found in other languages of the world, thus the examples used here have universal implications. By focusing our attention on the emergence of homonyms in modern Serbo-Croatian, we are able to view a linguistic change occuring in our own time in the variant of a language in transition.

Povzetek

\section{K IZVORU HOMONIMIJE V SLOVANSKIH JEZIKIH}

$\mathrm{V}$ prispevku obravnava avtor nekatere poglede na izvor in naravo homonimije $\mathrm{v}$ slovanskih jezikih, posebej $\mathrm{v}$ ruščini in srbohrvaščini. Navaja nekaj praslovanskih primerov, $k i$ so se $\mathrm{v}$ posameznih jezikih zaradi glasovnih sprememb, sprejemanja tujih leksikalnih prvin in razvejanega pregibanja besed zelo pomnožili. $V$ zvezi $s$ homonimijo se avtor dotika tudi nekaterih naglasnih vprašanj $\mathrm{v}$ razmerju hrvaške in srbske variante srbohrvaškega jezika. 